\title{
Experimental and theoretical assessment of the long-term strength of lightweight concrete and its components under compression and tension, taking into account the macrostructure of the material
}

\author{
Choriqul Raupov ${ }^{1 *}$, Anora Karimova ${ }^{1}$, Fakhriddin Zokirov $^{1}$ and Yoqutxon Khakimova ${ }^{1}$ \\ ${ }^{1}$ Tashkent State Transport University, 100067, Tashkent, Uzbekistan
}

\begin{abstract}
Experimental studies of concrete static fatigue require quite laborious and time-consuming tests. Insufficient data on static fatigue for concrete and the absence of an adequate theoretical base until recently did not allow using a generalized approach to estimate static fatigue parameters for different types of concrete. The paper presents the results of extensive experimental studies on static fatigue strength under tension and compression for lightweight concrete, mortar matrix, and hardened cement paste. A theoretical equation based on the fracture mechanics approach has been proposed and discussed for approximating experimental results and predicting static fatigue strength, which can be used for normalization of this parameter. The proposed equation displays better estimates compared to this used in the energy approach and empirical formulas.
\end{abstract}

\section{Introduction}

Static fatigue strength, $\mathrm{R}_{\mathrm{cl}}\left(\mathrm{t}, \tau_{1}\right)$ is one of the most important mechanical characteristics, which may be used for the rational design of concrete structures. The failure of concrete subjected to static sustained load which has been applied at an age $\tau_{1}$ and kept for a certain duration of time $t$ usually occurs at stresses 10 - 30\% smaller than its short-term static strength, Rc. Insufficient data on static fatigue for concrete-type materials and the absence of an adequate theoretical base until recently did not assess and normalize static fatigue strength for different types of concrete. A considerable difference of opinion still exists among the researchers on determining its nature and magnitude for different types of concrete in general and for lightweight concrete in particular. Published data on the relative limit of static fatigue strength, $\eta\left(t, \tau_{1}\right)=\mathrm{R}_{c l}\left(\mathrm{t}, \tau_{1}\right) / \mathrm{R}_{\mathrm{c}}$ are ranging from 0.7 to 0.9 for compression [1-3], and from 0.68 to 0.93 for tension [3,6] depending on the concrete type and its grade, curing condition, and age at the moment of loading.

Two main approaches are usually in use for experimental assessment of static fatigue strength, $\mathrm{R}_{\mathrm{cl}}\left(\mathrm{t}, \tau_{1}\right)$ :

\footnotetext{
${ }^{1}$ *Corresponding author: raupovch@gmail.com
} 
its comparison with the upper threshold of cracking, $\mathrm{R}_{\mathrm{vcrc}}$ detected on the stress-strain diagram at the stage of fast propagation of cracks which eventually link and cause failure during short-term tests; creep rupture may take place under the stress of $\sigma_{c l} \geq R_{v c r c}$ after a certain period of "critical time" interval of $\tau_{1} \leq\left(\mathrm{t}-\tau_{1}\right) \leq \mathrm{t}_{\mathrm{cr}}$, were tcr is "critical" duration of loading; $\tau_{1}$ and $t$ are ages of specimen at loading and failure instants respectively;

use of the actual values of $\mathrm{R}_{\mathrm{cl}}\left(\mathrm{t}, \tau_{1}\right)$ obtained at a higher level of stresses (which requires a consequently short duration of the test prior to failure of the specimen) with its extrapolation to a longer duration of the test at lower stresses.

These make experimental tests on static fatigue quite laborious and time-consuming. Furthermore, the complexity of the definition of $\mathrm{R}_{\mathrm{cl}}\left(\mathrm{t}, \tau_{1}\right)$ is determined by the fact that the short-term strength of concrete specimens exposed to long-term loading is not a subject of direct assessment. For this purpose, twin samples are usually tested, but strength variations affect the results of data analysis. This is a reason why, along with direct tests, a theoretical assessment of $\mathrm{R}_{\mathrm{cl}}\left(\mathrm{t}, \tau_{1}\right)$ is also of great importance. The various static fatigue theories have been developed for concrete; yet have not received wide use. Based on simple empirical equations $[1,6]$ or different rheological models derived from phenomenological considerations or energy concepts [2], they are, in general, not reflecting real physical mechanisms of the long-term fracture process, which depends on the age and structure of a material, properties and amount of its constituents, mixing and curing conditions.

A partial safety factor for material has been introduced in various codal documents to allow for the effect of concrete strength reduction under long-term loading. This factor also considers the effects of (i) increase of concrete stress due to gradual or sequenced load applications and (ii) positive effect of creep on the stress distribution between concrete and reinforcement. It is necessary to mark that the values of safety factor $\gamma c_{2}$ for material set up by the National Code [1] to allow for long-term loading, were recommended for practical use without essential experimental justification and simply by accepting the values obtained for normal heavyweight concrete, irrespective of acting stress level. At the same time, the noticeable differences in the behavior of lightweight concrete under the loading require allowances for higher strain and cracking capacities due to the higher brittleness of the material. A more deferential approach is required for the assignment of $\mathrm{R}_{\mathrm{cl}}\left(\mathrm{t}, \tau_{1}\right)$ for lightweight concrete.

\section{Materials and Methods}

\subsection{Theoretical approaches}

The relationship between a relative level of the sustained stresses $\eta\left(t, \tau_{1}\right)$ and duration of loading up to the moment of concrete specimen's failure can be expressed by equation (1) based on assumptions of linear fracture mechanics which has been applied (with certain approximations) for concrete-type materials [8]:

$$
\eta\left(t ; \tau_{1}\right)=\frac{m\left(t ; \tau_{1}\right) R_{c}(t)}{R_{c}\left(\tau_{1}\right)} \sqrt{\frac{1}{1+\mathrm{E}(t) \cdot C_{c}{ }^{*}\left(t ; \tau_{1}\right)}}
$$

where: $R_{c}\left(\tau_{1}\right)$ and $R_{c}(t)$ is short-term strength of concrete, determined at the ages of load application $\tau_{1}$ and failure $t$ respectively, $\mathrm{MPa} ; \mathrm{E}(\mathrm{t})$ is the module of elasticity of concrete at the age of $\mathrm{t}, \mathrm{MPa} ; \mathrm{Cc} *\left(\mathrm{t} ; \tau_{1}\right)$ is the value of linear creep measure of concrete at axial compression (i.e., creep strain related to the unit of acting long-term loading), MPa-1; $\mathrm{m}\left(\mathrm{t} ; \tau_{1}\right)$ is the function which takes into account influences of long term loading on the rate 
of instant strength development with time (or, in terms of fracture mechanics, on the rate of material surface energy change with time in a zone around the cracks);

In this approach, the fact that a crack reaches its critical length under the creep condition is considered a fracture criterion. The crack propagation process in concrete, mortar, and hardened cement paste has been considered taking the following two assumptions: (a) creep in the tension zone around the crack tip is linear; (b) rheological properties of the material in this zone are similar to those of entire material. Eq. (1) takes into account the effect of two opposite counteracting processes, i.e., the consolidation of the inner structure during the hardening and hydration of cement paste with time (first multiplier) and its loosening as a consequence of gradual crack propagation and creep of material (second multiplier). With time the creep development, and consequently cracking, slow down, and continuing process of cement paste hardening make a positive effect on concrete strength parameters. Therefore, according to eq. (1), starting from some "critical" moment of time, $t=t^{*}$, the value of $\eta\left(t, \tau_{1}\right)$ theoretically must increase. But since no failure occurs at ascending branch of " $\eta-t$ " diagram, then the minimum point at this diagram will correlate to both limit of static fatigue strength and "critical" time, $t^{*}$. One of the main advantages of formula (1) is its applicability to different types of concrete.

During the analysis of cracks development in cement paste and concrete prior to static failure [4, 7], it was accepted that the cracking takes place in mortar component only, assuming that porous lightweight aggregate particles by their low strength do not resist crack propagation, and the crack as though "sneaks" through it. Therefore, the rheological characteristics of a material that are necessary for the analysis of static fatigue strength of lightweight concrete are entirely related only to the tensile strength of the mortar matrix component of concrete. Stress distribution in the vicinity of developing cracks weakly depends on a type of external loading. The zone around the crack tip is mostly under a condition close to uniaxial tension. In this respect, the eq. (1) may be modified in form as follows:

$$
\eta\left(t, \tau_{1}\right)=\frac{m\left(t, \tau_{1}\right) R_{b}(t)}{R_{b}\left(\tau_{1}\right)} \sqrt{\frac{1}{1+\mathrm{E}(t) \cdot C_{c t}^{*}\left(t, \tau_{1}\right)}}
$$

where $\operatorname{Cct}^{*}\left(\mathrm{t} ; \tau_{1}\right)$ is the value of linear creep measure at axial tension for the mortar matrix component of lightweight concrete, $\mathrm{MPa}-1$;

It has to be noted that static fatigue under both tension and compression are the subjects of the same regularity that outcomes from failure mechanisms under tension and compression. To solve eq. (1) the values of $\mathrm{R}_{\mathrm{c}}\left(\tau_{1}\right), \mathrm{R}_{\mathrm{c}}(\mathrm{t}) \mathrm{Cct}^{*}\left(\mathrm{t} ; \tau_{1}\right), \mathrm{Cc}\left(\mathrm{t} ; \tau_{1}\right), \mathrm{E}(\mathrm{t})$ and $\mathrm{m}\left(\mathrm{t} ; \tau_{1}\right)$ should be known. Values for linear creep measure for mortar matrix component of concrete at an axial tension may be obtained from direct tests or defined using the following formula:

$$
C_{c t}^{*}\left(t ; \tau_{1}\right)=\lambda\left(t, \tau_{1}\right) C_{c}\left(t, \tau_{1}\right)
$$

Here Cc $\left(\mathrm{t}, \tau_{1}\right)=\theta\left(\tau_{1}\right) \mathrm{f}\left(\mathrm{t}-\tau_{1}\right)$ is a constitutive equation for compression creep measure [11], where $\theta\left(\tau_{1}\right)=\mathrm{C} 0+\mathrm{A} / \tau$ is a decreasing function defining the ageing of concrete, and $\mathrm{f}(\mathrm{t}-$ $\left.\tau_{1}\right)=1-e^{-\gamma\left(t-\tau_{1}\right)}$ is an exponential function accounting for the duration of loading; $\mathrm{C}_{0}$, A and $\gamma$ are the test constants.

The influence of long-term loading on the rate of instant strength development with time has been studied to quite a little extend. Still, there is a disagreement among researchers on whether a preceding long-term loading leads to the increase or decrease for both the material's short-term strength at compression, $\mathrm{R}_{\mathrm{c}}$ and tension $\mathrm{R}_{\mathrm{ct}}$ and module of 
elasticity, etc. Furthermore, no reliable data on these phenomena are available for lightweight concrete. In the current research, the estimation of $\mathrm{m}\left(\mathrm{t} ; \tau_{1}\right)$ have been done from direct test data by the formula derived in the following form:

$$
\mathrm{m}\left(\mathrm{t} ; \tau_{1}\right)=\mathrm{a}_{1}+\mathrm{b}_{1} \lg \left(\mathrm{t} ; \tau_{1}\right)
$$

The rate of strength growth $\mathrm{R}_{\mathrm{c}}(\mathrm{t}) / \mathrm{R}_{\mathrm{c}}\left(\tau_{1}\right)$ for lightweight concrete was estimated using simple empirical eq. (5) derived from extensive experimental studies and described in [9]:

$$
R_{c}(t)=R_{c} \frac{t}{0.75 t+7}
$$

A validation and adequacy of fracture mechanics approach described above has been assessed by comparison of its results with (a) those obtained using energy concept; (b) simple empirical expression frequently used for practical approximation; and (c) experimental data on the parametric threshold, Rvcrc, received from short-term tests.

An expression based on the energy method approach has been developed in [2] to assess $\eta\left(t, \tau_{1}\right)$. Although it doesn't contain the multiplier allowing for the growth of maturity in concrete, it is quite similar in appearance to that of eq. (1) and may be written in the following form:

$$
\eta\left(\mathrm{t}, \tau_{1}\right)=\frac{\mathrm{R}_{\mathrm{Cl}}\left(\mathrm{t}, \tau_{1}\right)}{\mathrm{R}_{\mathrm{C}}}=\sqrt{\frac{1}{1+d K_{C} E(t) C_{c} *\left(t ; \tau_{1}\right)}}
$$

Where: $d=\frac{K_{\text {rec.creep. }}}{K_{\text {rec.inst }}} \times \frac{(2+m)}{\left(2+m+2 \eta_{\text {inst }}\right)}$;

Here: $\mathrm{K}_{\mathrm{c}}$, is proportionality coefficient; $\mathrm{K}_{\text {rec.inst }}$ and $\mathrm{K}_{\text {rec.creep }}$ are respective coefficients allowing for recovery of instant and creep deformations; $m$ and $\eta$ inst are the coefficients to be calculated using real short-term and long-term curves obtained from experiments.

In cases when direct test data for the components in equations (2) and (6) are not available, then the estimation of $\eta\left(t, \tau_{1}\right)$ may be done approximately using well-known empirical logarithmic expression [6]:

$$
\eta\left(t ; \tau_{1}\right)=a_{2}-b_{2} \lg \left(t-\tau_{1}\right)
$$

Where the coefficients $\mathrm{a}$ and $\mathrm{b}$ can be assigned using published experimental creep data available for the particular type of concrete.

The main disadvantage of eq. (7) is the existence of finite time duration for failure at any applied stress, including $\sigma_{\mathrm{cl}}=0$. Therefore, the extrapolation of eq. (7) for longer durations gives under-estimated values for $\eta\left(t, \tau_{1}\right)$, which is favorable regarding the safety, but not economical enough. Hence, the correct extrapolation will be up to the critical moment of time $t^{*}$, which represents the time interval within which the failure under longterm loading may be expected.

\subsection{Testing programme}

The appropriate tests were carried out to determine the static fatigue strength characteristics using the standard testing procedure for long-term compression and tension of specimens made from lightweight concrete, mortar matrix, and hardened cement paste. The test set up 
is shown in Figure 1. High intensity sustained load has been created using spring and levered rigs with a maximum capacity of 210 and $30 \mathrm{kN}$, respectively. Necessary precautions were observed to exclude the errors due to temperature effects and nonadditivity of creep and shrinkage of specimens. Structural characteristics and specifications of the materials used for the tested specimens are given in Tab. 1.

Table 1

\begin{tabular}{|c|c|c|c|c|c|c|c|c|c|c|}
\hline \multirow[b]{2}{*}{$\cdot \stackrel{\infty}{\frac{\infty}{\infty}}$} & \multicolumn{3}{|c|}{$\begin{array}{l}\text { Actual expenditure of } \\
\text { materials on } 1 \mathrm{~m}^{3} \text { of } \\
\text { concrete }\end{array}$} & \multirow[b]{2}{*}{$\mathrm{W} / \mathrm{C}$} & \multicolumn{2}{|c|}{$\begin{array}{c}\text { Volumetric } \\
\text { mass of }\end{array}$} & \multirow[b]{2}{*}{$\begin{array}{l}\mathrm{E}_{\mathrm{c}} \\
\mathrm{GPa}\end{array}$} & \multirow[b]{2}{*}{$\begin{array}{c}\mathrm{R}, \\
\mathrm{MPa}\end{array}$} & \multirow[b]{2}{*}{$\begin{array}{l}\mathrm{R}_{\mathrm{c}} \\
\mathrm{MPa}\end{array}$} & \multirow[b]{2}{*}{$\mathrm{R}_{\mathrm{c}} / \mathrm{R}$} \\
\hline & 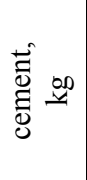 & 胥 & 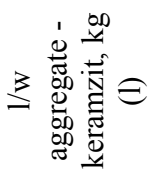 & & 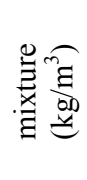 & 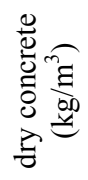 & & & & \\
\hline $\mathrm{CL}$ & 443 & 897 & $284(500)$ & 0.51 & 1980 & 1940 & 19.1 & 36.9 & 32.4 & 0.88 \\
\hline $\mathrm{CM}$ & 429 & 766 & $352(620)$ & 0.50 & 1885 & 1833 & 17.7 & 33.9 & 26.5 & 0.78 \\
\hline $\mathrm{CH}$ & 427 & 629 & $414(727)$ & 0.49 & 1810 & 1760 & 15.4 & 33.0 & 28.4 & 0.86 \\
\hline MM & 669 & $\begin{array}{c}122 \\
8\end{array}$ & - & 0.35 & - & - & - & - & - & - \\
\hline $\mathrm{HCP}$ & $\begin{array}{c}172 \\
2 \\
\end{array}$ & - & - & 0.36 & - & - & - & 45.0 & - & - \\
\hline
\end{tabular}

*Structure and characteristics of tested specimens
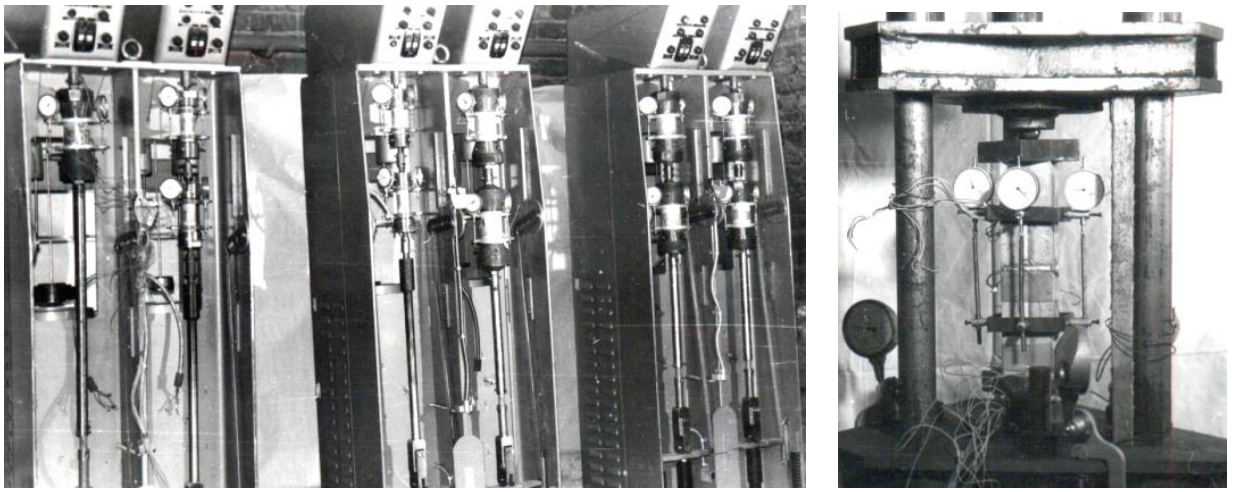

Fig.1. The test set up for long-term tension (a) and compression (b)

Here the abbreviations CL, CM, and C.H. were used to designate concrete mixes with low, average, and high contents of coarse aggregate, respectively; $\mathrm{MM}$ - for mortar specimens representing a matrix of $\mathrm{CM}$ concrete mix;

HCP - for specimens made from cement paste with the w/c ratio providing a standard consistency. As a coarse aggregate, keramzit (expanded clay) gravel was used in all concrete mixes with two fraction sizes of 5-10 and $10-20 \mathrm{~mm}$ at a volume ratio $40 \% / 60 \%$. To estimate the effect of aggregates on $\mathrm{Rcl}\left(\mathrm{t}, \tau_{1}\right)$ values, concrete mixes were designed so that to have a maximum possible variation in fine and coarse aggregate contents with minimum variations in concrete strength values. The samples were cured for 7 months before testing when the strength parameters of the materials are practically stabilized. The slump of a cone for the concrete mixture constituted from 1 to $2 \mathrm{~cm}$.

Under short-term loading, prisms of $150 \times 150 \times 600$ and $70 \times 70 \times 280 \mathrm{~mm}$ were tested under compression and cylinders of $70 \times 235 \mathrm{~mm}$ (diameter $\mathrm{x}$ height) under tension to obtain stress-strain diagrams and values of the material strength under bot compressions, $R_{c}$ 
and tension, $\mathrm{R}_{\mathrm{ct}}$, modulus of elasticity, $\mathrm{E}_{\mathrm{b}}$ and Poisson's coefficient, $\mu$. Short-term tests of mortar and cement paste specimens at compression were performed on prisms of $40 \mathrm{x} 40 \mathrm{x}$ $160 \mathrm{~mm}$ and at the tension on cylinders of $70 \times 235 \mathrm{~mm}$ and $40 \times 160 \mathrm{~mm}$. Under long-term tension and compression tests were carried out on prisms of $70 \times 70 \times 280 \mathrm{~mm}$ and cylinders of $70 \times 235 \mathrm{~mm}$ for concrete and on prisms of $40 \times 40 \times 160 \mathrm{~mm}$ and cylinders of $40 \times 160 \mathrm{~mm}$ for mortar and cement paste. Cube specimens of 70 and $150 \mathrm{~mm}$ were used for concrete, and $40 \mathrm{~mm}$ for mortar and cement paste to obtain cube strength, R. Results of tests under short-term loading are given in Tab.2.

Table 2

\begin{tabular}{|c|c|c|c|c|c|c|c|c|c|c|c|c|}
\hline \multirow{3}{*}{$\begin{array}{c}\text { Seri } \\
\text { es }\end{array}$} & \multicolumn{9}{|c|}{$R, \mathrm{MPa}$} & \multicolumn{6}{c|}{$R_{\mathrm{c}} / R_{\mathrm{ct}}$} & \multicolumn{5}{c|}{$\mathrm{E}_{\mathrm{b}}, \mathrm{GPa}$} & $\mu$ \\
\cline { 2 - 13 } & 220 & 530 & 800 & 220 & 530 & 800 & 220 & 530 & 800 & 220 & 800 \\
\hline \multirow{2}{*}{ CL } & 39.2 & 44.8 & 48.0 & $33.2 / 2.54$ & $37.2 / 2.63$ & 37.4 & 21.6 & 26.2 & 26.0 & 0.19 & \\
CM & 42.5 & 45.9 & 53.0 & $35.9 / 2.25$ & $27.3 / 2.29$ & 37.8 & 19.8 & 23.5 & 23.6 & 0.19 & 0.19 \\
CH & 36.5 & 43.5 & 48.2 & $34.3 / 2.06$ & $37.4 / 2.30$ & 35.7 & 18.7 & 22.0 & 22.9 & 0.20 & 0.20 \\
MM & 78.3 & 48.1 & 48.4 & $48.4 / 4.49$ & $51.3 / 3.77$ & - & 29.5 & 32.1 & - & 0.20 & 0.20 \\
HCP & 119. & 114. & - & $98.4 / 3.08$ & $98.1 / 3.30$ & - & 22.6 & 26.5 & - & 0.23 & \\
\hline
\end{tabular}

*Test results at short-term loading

The total number of specimens tested under long-term loading was 47 for compression and 50 under tension. The development of deformations during the creep tests in all failed samples undergo three specific stages: (i) fast growth immediately after loading; (ii) slowing down after a short period of time, and (iii) accelerated growth prior to the failure accompanied by significant lateral strains due to the progressive cracking.

\section{Results and Discussion}

The relative limit of static fatigue strength has to be taken as a minimum value of a relative level of sustained stress $\sigma_{\mathrm{cl}} / \mathrm{R}_{\mathrm{cl}}\left(\mathrm{t}, \tau_{1}\right)$, resulting in failure of a material after the unlimited long period of endurance loading. $\mathrm{E}_{\mathrm{q}}$. (2) has been used to calculate theoretical curves (see Fig. 2). The values of short-term strength, a module of elasticity, specific creep, and $m\left(t ; \tau_{1}\right)$ function, used in the formula, were accepted by results of the tests which have been carried out on twin specimens made from a material of the same structure and age and cured under the same conditions of the environment.

The values of $\mathrm{C}_{, 0}$, $\mathrm{A}$ and $\gamma$ have been selected by the trial procedure so that eq. (3) may be rewritten as:

$$
\begin{gathered}
C_{c}\left(t ; \tau_{1}\right)=\frac{70 R_{c}^{2}\left(\tau_{1}-2\right)+13000 R_{c}-140000}{\left(177 R_{c}-1700\right) R_{c} \tau_{1}^{3 / 2}} \times 10^{-5}+\frac{0.2 R_{c}+15 \tau_{1}-2 R_{c}+100}{R_{c}} \times\left[1-e^{-\gamma\left(t-\tau_{1}\right)}\right] \times 10^{-5}, \\
\gamma=0.015+18 / R_{c} ; \quad \lambda\left(t ; \tau_{1}\right)=a+b\left(t-\tau_{1}\right) / t_{1}
\end{gathered}
$$

For lightweight concrete of dense structure (using quartz sand as a fine aggregate): $\mathrm{a}=2.15 ; \mathrm{b}=0.63$ at $0<\left(\mathrm{t}-\tau_{1}\right) \leq 2$ days; $\mathrm{a}=3.40 ; \mathrm{b}=-0.077$ at $2<\left(\mathrm{t}-\tau_{1}\right) \leq 15$ days; $\mathrm{a}=2.25 ; \mathrm{b}=-0.03$ at $15<\left(\mathrm{t}-\tau_{1}\right) \leq 100$ days; $\mathrm{a}=2.00 ; \mathrm{b}=0$ at $\left(\mathrm{t}-\tau_{1}\right)>100$ days;

For lightweight concrete of porous structure (using lightweight keramzit sand):

$\mathrm{a}=2.0 ; \mathrm{b}=1.0$ at $0<\left(\mathrm{t}-\tau_{1}\right) \leq 2$ days; $\mathrm{a}=4.06 ; \mathrm{b}=0.03$ at $2<\left(\mathrm{t}-\tau_{1}\right) \leq 100$ days; $\mathrm{a}=1.0 ; \mathrm{b}=0$ at $\left(\mathrm{t}-\tau_{1}\right)>100$ days. 
All values necessary for calculation of $\mathrm{C}_{\mathrm{bt}} *\left(t ; \tau_{1}\right), \mathrm{C}_{\mathrm{b}}\left(\mathrm{t} ; \tau_{1}\right)$ and $\mathrm{m}\left(\mathrm{t} ; \tau_{1}\right)$ in eq. (2) and (3) have been obtained from direct creep tests of the same twin specimens; the methodology and results of these studies have been discussed elsewhere [ 7, 8-20]. For the best fit, the values of coefficients in eq. (4) for function $\mathrm{m}\left(\mathrm{t} ; \tau_{1}\right)$ were calculated as: $\mathrm{a}_{1}=1.091 ; \mathrm{b}_{1}=$ 0.035 for specimens age, $\tau_{1} \leq 28$ days; and $a_{1}=1.033 ; b_{1}=0.029$ for $\tau_{1}>28$ days. For this purpose, a part of creep specimens under the load of $(0.2 \ldots 0.7) R_{c}$ and $0.3 R_{\text {ct }}$ were unloaded at the age of 210 days; after registration of creep recovery deformations during 56 days, they were tested under short-term static load until failure. In the absence of reliable test data, the values of $\mathrm{m}\left(\mathrm{t} ; \tau_{1}\right)$ may be taken equal to 1.1 .



a)

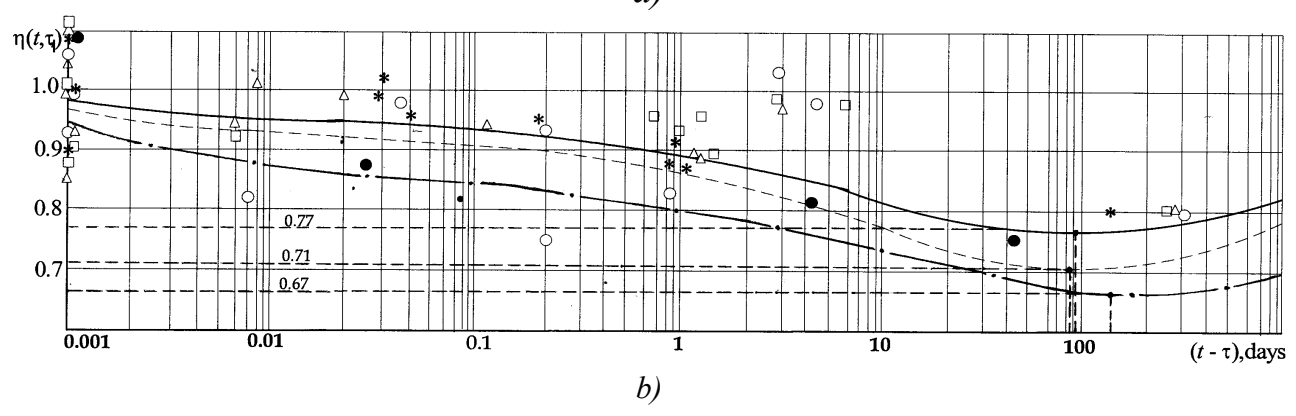

Fig.2. Data approximation for tension (a) and compression (b) tests by eq. (2): —— lightweight concrete; - - - mortar matrix; —_ - - hardened cement paste ( $-\mathrm{CL} ; \Delta-\mathrm{CM}$; $\square-\mathrm{C} . \mathrm{H}$.; * $\mathrm{MM} ; \bullet-\mathrm{HCP})$

It is visible from the diagrams in Fig. 2 that conformity between theoretical and experimental data can be considered satisfactory. Note that starting from the critical moment of time $\mathrm{t}=\mathrm{t}^{*}$, theoretical static fatigue strength commences to grow as predicted. It occurs because the preceding process of hydration in a hardening cement paste starts to play a prevailing role compared to creep deformations and cracking, which fade with time. However, physically to obtain failure at $\mathrm{t}>\mathrm{t} *$ appears impossible - it will always occur at $\mathrm{t}$ $<\mathrm{t}^{*}$, therefore the limit level of static fatigue strength was defined as the minimal ordinate of a curve (horizontal dashed lines on Fig. 2; arrows show that the specimens under consideration have not failed) 


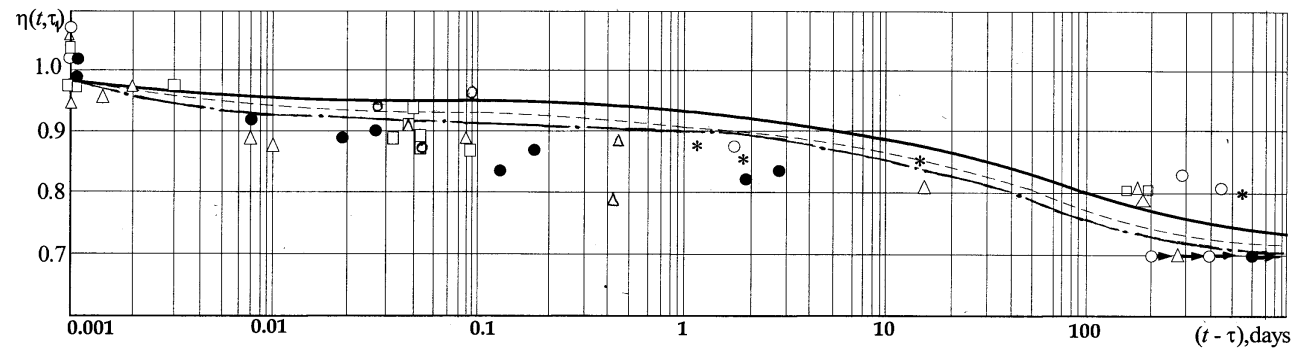

a)

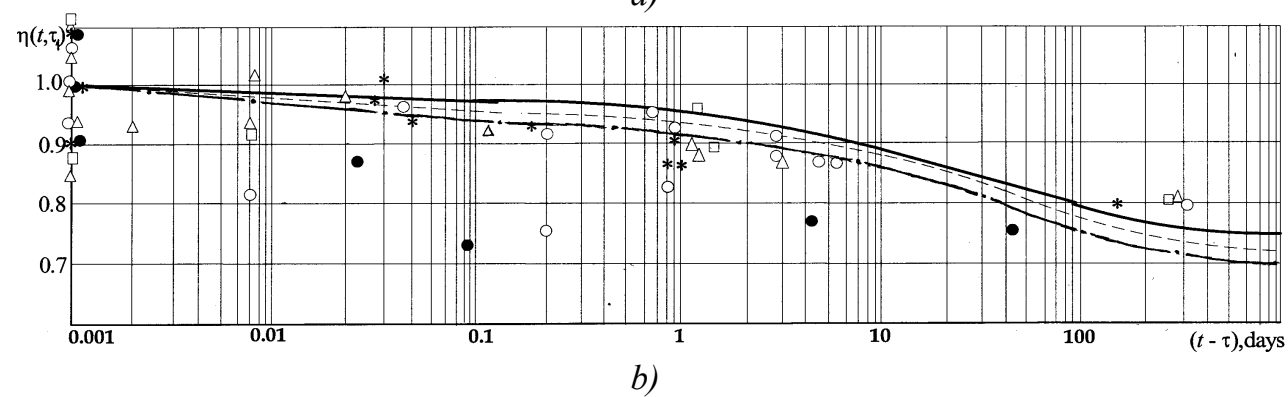

Fig.3. Data approximation for tension (a) and compression (b) tests by eq. (6): - lightweight

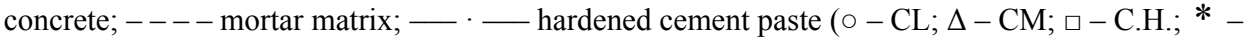
$\mathrm{MM} ; \bullet-\mathrm{HCP})$

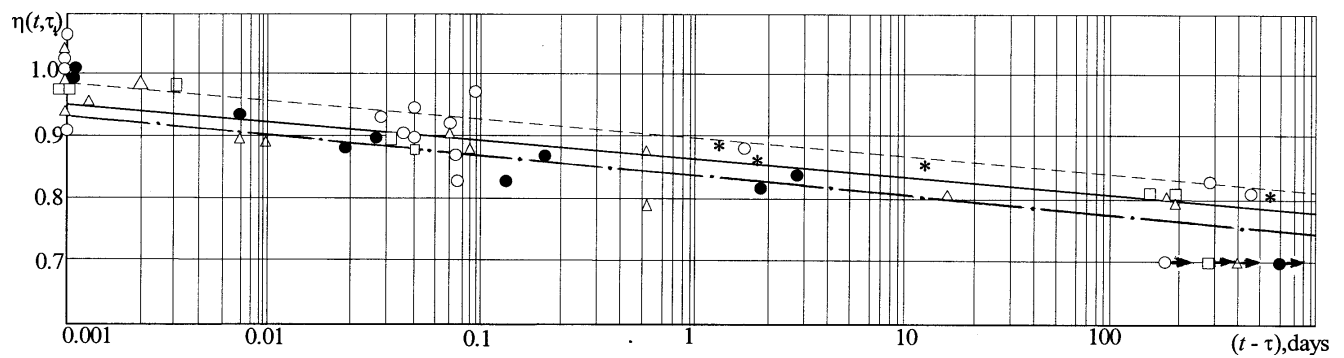

a)

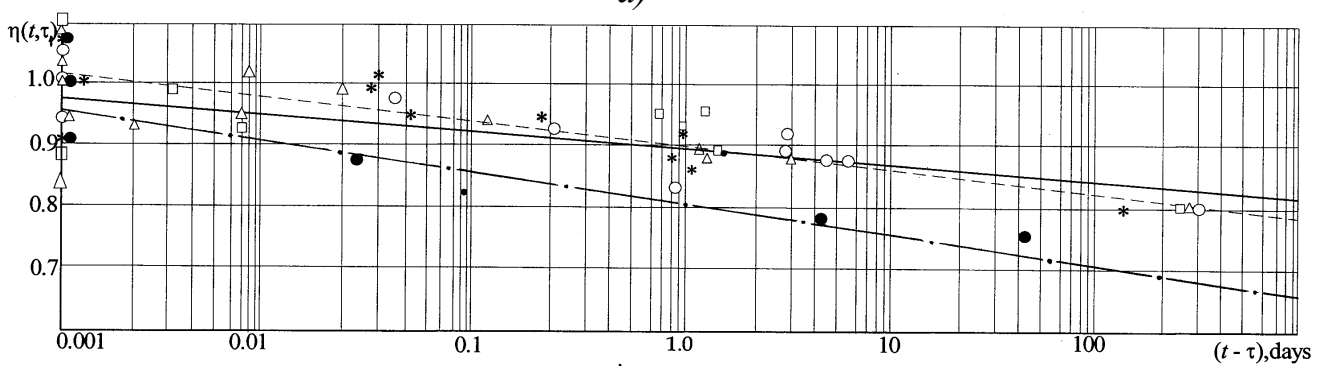

b)

Fig.4. Data approximation for tension (a) and compression (b) tests by eq. (7): - lightweight

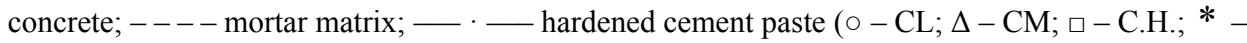
$\mathrm{MM} ; \bullet-\mathrm{HCP})$

The results of the calculations according to equations (6) and (7) with regard to the other two different approaches mentioned above are presented in Figures 3 and 4, respectively showing the best-fit approximation curves for $\eta\left(t, \tau_{1}\right)$ test values obtained under long-term compression and tension. The coefficients in eq. (6) were determined using real short-term 
and long-term deformation diagrams obtained from experiments performed on similar specimens. These experiments are not reported but available in [9-20]- the values for coefficients in the eq. (7) were calculated using the least squares method and are given in Table 3 .

Table 3

\begin{tabular}{|c|c|c|c|c|c|c|}
\hline \multirow{2}{*}{ Coefficients } & \multicolumn{6}{|c|}{ Values of coefficients for series of specimens } \\
\cline { 2 - 7 } & CL & CM & CH & Average & MM & HCP \\
\hline \multicolumn{7}{|c|}{ Axial compression } \\
\hline$a_{2}$ & 0.873 & 0.841 & 0.864 & 0.859 & 0.886 & 0.831 \\
\hline$b_{2}$ & 0.044 & 0.033 & 0.053 & 0.048 & 0.029 & 0.042 \\
\hline \multicolumn{7}{|c|}{ Axial tension } \\
\hline$a_{2}$ & 0.847 & 0.859 & 0.906 & 0.865 & 0.896 & 0.801 \\
\hline$b_{2}$ & 0.047 & 0.041 & 0.048 & 0.052 & 0.064 & 0.036 \\
\hline
\end{tabular}

*Calculated values of coefficients $a_{2}$ and $b_{2}$ for the function of $m\left(t ; \tau_{1}\right)$

From test results, it is observed that the values of $R_{c l}$ for the samples with different content of cement and aggregate depends considerably on materials microstructure increasing along with the transition from one-component structure to two- and threecomponent structure. Figure 5 shows graphically that with the increase of the amount of coarse aggregate in lightweight concrete static fatigue strength decreases under compression and increases under tension.

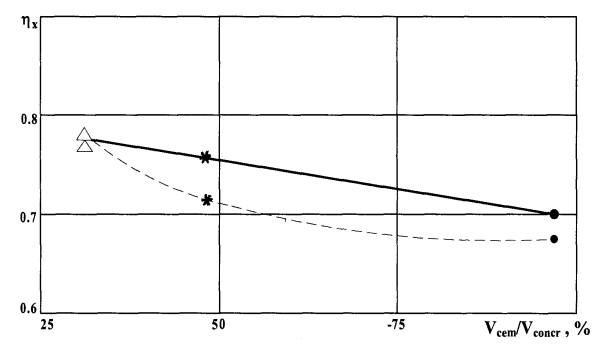

a)

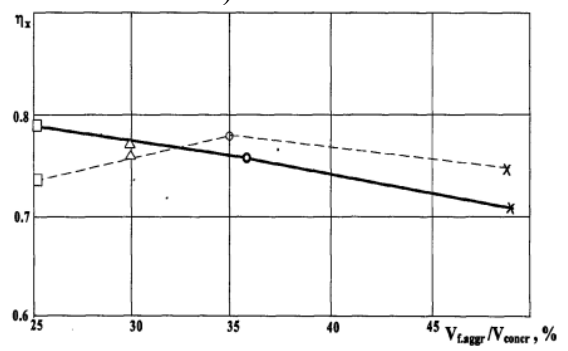

b)

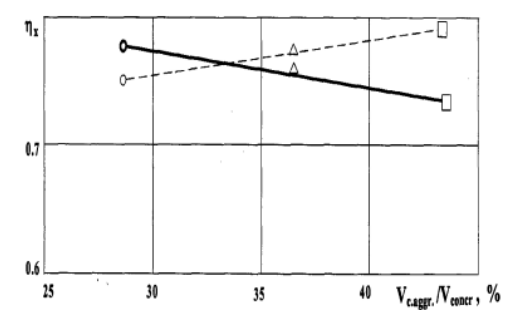


v)

Fig.4. Influence of the content of cement (Vcem / Vconcr), fine (Vf.aggr / Vconcr) and coarse (Vf.aggr / Vconcr) aggregates on static fatigue strength: —— compression; - - - tension ( $\mathrm{O}-\mathrm{CL}$; $\left.\Delta-\mathrm{CM} ; \square-\mathrm{CH} ;{ }^{*}-\mathrm{MM} ; \bullet-\mathrm{HCP}\right)$

The conformity between $\eta\left(t, \tau_{1}\right)$ and parametric threshold of cracking, Rvcrc was a subject of special attention since it allows the determination of $\eta\left(t, \tau_{1}\right)$ using using the results of short-term tests. During the short-term testing, the values of $\mathrm{R}_{\mathrm{vcrc}}$ were determined using volumetric stress-strain diagrams. The diagrams were obtained during both monotonic and cyclic loading and based on direct strain measurements using electric strain gauges. Simultaneously, the parameters of acoustic emission were determined using a special device AVN-3, which allowed to register several acoustic signals due to the formation of unstable internal cracking over the entire sample with respect to the loading level. The values of $R_{v c r c}$ were corresponded to the last peaks on the diagram of emitted acoustic signals exhibiting rapid changes in the internal structure before failure. The methodology and measurement technique used during acoustic tests are not reported but available in $[9,15-20]$. The results of these tests are given in Table 4 where abbreviations ESG and A.E. were used to designate the use of electric strain gauge and acoustic emission methods. Comparison of $\mathrm{R}_{\mathrm{vcrc}}$ and $\mathrm{R}_{\mathrm{cl}}$ values obtained shows that the best conformity takes place for the concrete and cement paste samples subjected to cyclic loading and for mortar samples at monotonic loading.

Table 4

\begin{tabular}{|c|c|c|c|c|c|c|c|c|c|c|}
\hline \multirow[b]{4}{*}{$\begin{array}{c}\text { Serie } \\
\mathrm{s}\end{array}$} & \multicolumn{7}{|c|}{ Compression } & \multicolumn{3}{|c|}{ Tension } \\
\hline & \multicolumn{3}{|c|}{$R_{v c r c} / R_{c}$} & \multirow[b]{3}{*}{$\begin{array}{c}R_{c l} / \\
R_{c}\end{array}$} & \multicolumn{3}{|c|}{$R_{v c r c} / R_{c l}$} & \multirow{3}{*}{ 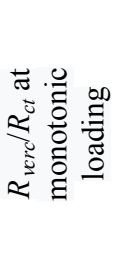 } & \multirow[b]{3}{*}{$\frac{\approx}{2}$} & \multirow[b]{3}{*}{$\underset{2}{2}$} \\
\hline & \multicolumn{2}{|c|}{ ESG } & \multirow[b]{2}{*}{$\mathrm{AE}$} & & \multicolumn{2}{|c|}{ ESG } & \multirow[b]{2}{*}{$\mathrm{AE}$} & & & \\
\hline & 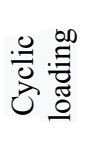 & 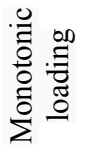 & & & 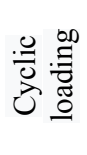 & 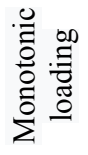 & & & & \\
\hline CL & 0.72 & 0.80 & 0.77 & 0.77 & 0.94 & 1.04 & 1.00 & 0.85 & 0.75 & 1.13 \\
\hline $\mathrm{CM}$ & 0.88 & 0.95 & 0.75 & 0.76 & 1.16 & 1.25 & 0.98 & 0.79 & 0.77 & 1.03 \\
\hline $\mathrm{CL}$ & 0.81 & 0.94 & 0.75 & 0.74 & 1.09 & 1.27 & 0.98 & 0.75 & 0.79 & 0.95 \\
\hline MM & 0.69 & 0.78 & - & 0.75 & 0.92 & 1.04 & - & 0.86 & 0.71 & 1.21 \\
\hline $\mathrm{HCP}$ & 0.88 & 0.88 & - & 0.70 & 1.26 & 1.26 & - & 0.69 & 0.67 & 1.03 \\
\hline
\end{tabular}

*Comparison of $R_{v c r c}$ and $R_{c l}$ values for tested specimens

\section{Conclusions}

It may be concluded that the character of change of static fatigue strength for lightweight concrete at uniaxial sustained loading can be described in terms of the fracture mechanics approach. Assuming physical failure criteria proposed, creep values of lightweight concrete at compression may be replaced by creep values for mortar matrix components at a tension. Equation (2) with sufficient accuracy (not exceeding 10\%) approximates experimental data and can be used for the purposes of normalization and prediction of static fatigue strength values for different types of lightweight concrete at uniaxial loading. The proposed expression for static fatigue strength has a sufficient agreement with empirical expressions and those developed within the energy approach.

New test data has been acquired on static fatigue strength for lightweight concrete and its constituents at uniaxial tension and compression with regard to their internal structure of 
the material. It is established that the static fatigue strength is highly dependent on parameters of inner structure: with the increase of the amount of coarse lightweight aggregate, the static fatigue strength decreases under compression and increases under tension.

It is confirmed that acceptable conformity exists between static fatigue strength and parametric threshold of cracking, $\mathrm{R}_{\mathrm{vcrc}}$; the best conformity takes place for the values of $\mathrm{R}_{v \text { crc }}$ obtained for concrete and cement paste samples subjected to cyclic loading and for mortar samples at monotonic loading; the failure of concrete under long-term loading, $\sigma_{\mathrm{cl}} \geq$ $\mathrm{R}_{\mathrm{cl}}$ take place in the time interval, $\mathrm{t}$ which do not exceed certain 'critical' time, $\mathrm{t}^{*}$.

\section{References}

1. Berg O.Y., Scherbakov E.N., Pisanko G.N. High strength concrete. "Stroyizdat" Moscow, 1982.

2. Bondarenko V.M., Bondarenko S.V. Engineering methods in non-linear theory of reinforced concrete. "Stroyizdat" - Moscow, 1982.

3. Rush, H., Researches towards a general flexural theory for structural concrete, ACI Journ., Vol. 57, №1, pp.1 - 28, 1966.

4. Bakradze D.D. The Study of long-term strength of lightweight concrete. PhD Thesis: Tbilisi, I980. - 140 pp.

5. National Codes of Practice for Design of Reinforced Concrete Elements (SNIP 2.03.01-84. Concrete and reinforced concrete structures). - Moscow, 1985.- p. 79.

6. Yashin A.V., Theory of strength and deformations of concrete concerning its structural changes and duration of loading. In: New studies of R.C. structures at limit states. Moscow: NIIZhB, 1982.

7. Ashrabov A.A. Modeling of properties and failure processes of lightweight concrete. "Science" - Tashkent, 1988. - 148 pp.

8. Ashrabov A.A., Zaytsev Y.V. Elements of fracture mechanics of concrete. "Ukituvchi"Tashkent., 1982. - 238 pp.

9. Ashrabov, A.A., Raupov, Ch. S. The study of long-term strength of lightweight concrete at compression and tension with regard to its structure. Research Works of VSPI.- Moscow, 1987. pp. $30-34$.

10. M.M. Smadi, F.O. Slate, A.H. Nilson. High-, medium-, and low-strength concretes subject to sustained overloads - strains, strength, and failure mechanisms. ACI Journal, - 1985, pp. $657-664$.

11. Arutyunyan, N.H. Some problems on theory of creep. Moscow - Leningrad, Gostechizdat, $1952-323 \mathrm{p}$.

12. U. Shermuxamedov, S.Salixanov, S.Shaumarov, F.Zokirov. Method of selecting optimal parameters of seismic-proof bearing parts of bridges and overpasses on high- speed railway lines // European Journal of Molecular \& Clinical Medicine, ISSN 2515-8260, 2020. Volume 7, Issue 2, Pages 1076-1084.

13. U.Z. Shermukhamedov, T.R. Rashidov. Features of the theory of a two-mass system with a rigidly connected end of the bridge, in consideration of seismic influence on high-speed railways // European Journal of Molecular \& Clinical Medicine, ISSN 2515-8260, 2020. Volume 7, Issue 2, Pages 1160-1166.

14. Bekmirzaev D A, Kishanov R U and Mansurova N S 2020 Mathematical Simulation and Solution of the Problem of Seismo-Dynamics of Underground Pipelines Int. J. Emerg. Trends Eng. Res. 8 5028-33.

15. Ashrabov A.A., Kon G.N., Raupov Ch.S., Shodzhalilov Sh.Sh. Comparisons of borders microcracking from long urability lightweight concrete at compression and the stretching. II Internationl Conference «Science Technologi in XXI Centure» Abstacts. Tashkent, 2003. XI. pp. 219.

16. Ashrabov A.А., Кон г.н., Раупов Ч.С., Садыков А.И. Исследование границ линейной ползучести керамзитобетона при сжатии. Сборник трудов Межд. конф. «Наука и технология в XXI веке». Ташкент, Ноябрь 2003 с. 70-73. 
17. Ashrabov A.А., Кон Г.Н., Раупов Ч.С., Шоджалилов Ш.Ш. Сопоставления границ микротрещинообразования с длительной прочности керамзитобетона при сжатии и растяжении. Сборник трудов Межд. конф. «Наука и технология в XXI веке». Ташкент, 18-22 ноябрь 2003. с. 73-78.

18. Raupov Ch.S. Рекомендуемые области применения керамзитобетона в мостостроении и его эффективность. Вестник ТашИИТа. 2010 №3.

19. Ashrabov, A. A., M. S. Jaafar, G. N. Kon, C. S. Raupov, A. I. Sadykov, Studies on limits of linear creep at compression for lightweight concrete. Proceedings of the Second International Uzbek-Korean Symposium "Science and Technology in 21st Century", Tashkent, 2004. 18 - 22 November, pp. $21-29$.

20. Raupov Ch.S. Практические предложения по учету деформации усадки и ползучести керамзитобетона при расчете мостовых конструкций. Вестник ТашИИТа. 2010 №4. 